\title{
Indonesia's Export-Import Prediction: A Hybrid Moving Average Approach
}

\author{
Seng Hansun, Marcel Bonar Kristanda, and P.M. Winarno \\ Informatics Department, Universitas Multimedia Nusantara, \\ Jl. Scientia Boulevard, Gading Serpong, Tangerang, Banten-15811 Indonesia.
}

\begin{abstract}
Indonesia as one of the largest countries in Asia Pacific region plays a crucial role in international trading. Since both the import and export performance have become key variables in economic growth of a nation, the urgent to have a proper prediction and analysis of those variables has become a major issue. In this study, we try to address the issue by using a relatively new hybrid moving average approach, i.e. the WEMA (Weighted Exponential Moving Average) method. Using different parameters, it has been shown that WEMA approach could predict Indonesia's export-import future values. Based on MAPE (Mean Absolute Percentage Error) and MASE (Mean Absolute Scaled Error) values as forecast error measurement criteria, WEMA gives the best performance in predicting Indonesia's export weight in $\mathrm{kg}$ unit.
\end{abstract}

Key words: economic growth, hybrid moving average, international trades, Indonesia's export-import, prediction

\section{INTRODUCTION}

In this 'global' era, international trading between nations has become one of key economic variables. Therefore, forecasts of exports and imports of major trading countries and regional blocks become a central feature of providers in economic forecasts [1]. The International Monetary Fund (IMF) and Organisation for Economic Co-operation and Development (OECD) as two leading providers of macroeconomics and forecasts at international level also included the import and export performance as a key factor.

Indonesia as one of the largest countries in Asia Pacific region also plays an important role in international trades. It has many potential and eminent products that become export commodities. Ten eminent export commodities of Indonesia are Textile and its products, Electronics, Rubber and its products, Palm oil, Forest products, Footwear, Automotive, Shrimp, Cocoa, and Coffee [2]. The export value of Indonesia's commodities also has a rising trend. Based on January to October 2017 report, Indonesia's export value to seven main destination countries, i.e. Japan, South Korea, Taiwan, China, Singapore, USA, and Germany, has increased $17.62 \%$ than the same period of last year [3].

Although exports' impact on economic development is more than imports since it is more related to domestic activities [4], the urgent to have a proper prediction and analysis of both export and import has become a major issue. It can be clearly seen through the vast amount of research papers that mainly questioned the relationship between export, import, and economic growth of a nation. Darman, for example, has studied and analyzed the international trade relations in export and import of goods between Indonesia and USA [5]. Ustriaji [6] also conducted a research to investigate the growth, contribution, and competitiveness of excellent commodity exports from Indonesia to the international world. Cetintas and Barisik [7] have analyzed the relationships between export, import, and economic growth for the 13 transition economies. Moreover, Dasgupta [8] and Velnampy and Achchuthan [9] have conducted and answered the same research question related to specific countries, i.e. India and Sri Lanka. In this study, we further developed the same question related to the export and import performance of a nation, especially Republic of Indonesia, using a relatively new hybrid moving average approach. The hybrid moving

Corresponding Author: Seng Hansun, Informatics Department, Universitas Multimedia Nusantara, J1. Scientia Boulevard, Gading Serpong, Tangerang, Banten-15811 Indonesia, hansun@umn.ac.id 
average method which is taken into consideration is the Weighted Exponential Moving Average (WEMA) method that had been introduced in 2013. Since its first appearance, WEMA has been widely used in time series analysis and forecasting as an alternative method, as we can see from the works of Chen et al. [10] and Hansun et al. [11-13].

Furthermore, the organization of this paper can be explained as follows. In the next section, WEMA as a time series approach and hybrid moving average method will be explained briefly. Its building block methods, i.e. Weighted Moving Average (WMA) and Exponential Moving Average (EMA), will be discussed after that. Following the methods explanation, Mean Absolute Percentage Error (MAPE) and Mean Absolute Scaled Error (MASE) as two unit-free forecast error measurement tools will be presented. The export and import prediction results then will be depicted and analyzed in the Results and Discussion section. Some concluding remarks and future suggestions will end the paper's presentation.

\section{WEMA AS A TIME SERIES APPROACH}

\section{WEMA Method}

WEMA is a relatively new hybrid forecasting method in Moving Average (MA) family that combines the weighting factors calculation in WMA with EMA procedures [14]. It has been proven to be a better forecasting technique than its building block methods which will be described later. Figure 1 shows a diagram of WEMA method to be implemented in this study.

Calculate the base value using WMA method

$$
H_{t}=\frac{n P_{M}+(n-1) P_{M-1}+\cdots+2 P_{(M-n+2)}+P_{(M-n+1)}}{n+(n-1)+\cdots+2+1}
$$

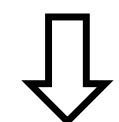

Using the base value, calculate the prediction value using

where $0 \leq \alpha \leq 1$.

$$
W E M A_{t}=\alpha \cdot Y_{t}+(1-\alpha) \cdot H_{t}
$$

Fig 1 WEMA's procedures

\section{WMA and EMA as Building Block Methods}

WMA is a Simple Moving Average (SMA) with a constant weight decrement from the newest datum to the older one. Using our own notation from Zakamulin [15], WMA formulation can be written as

$$
W M A_{n}=\frac{\sum_{t=k-n+1}^{k} w_{t} A_{t}}{\sum_{t=k-n+1}^{k} w_{t}}
$$

where $n$ is the span data, $k$ is the relative position of the period currently being considered within the total number of periods, $A_{t}$ is the actual value at time $t$, and $w_{t}$ is the weight of data $A_{t}$.

EMA is a better and improved version of WMA, which is originated from Brown's work, who was assigned to develop a tracking model for fire-control information on the location of US Navy submarines [16]. EMA also puts a greater weight to more recent data, but in exponentially manner. As described in [17], EMA for time series $Y$ can be calculated recursively using

$$
\begin{gathered}
S_{1}=Y_{1}, \\
\text { for } t>1, S_{t}=\alpha \cdot Y_{t}+(1-\alpha) \cdot S_{t-1}
\end{gathered}
$$

where $Y_{t}$ is the value at time period $t, S_{t}$ is EMA value at time $t$, and $\alpha$ represents the constant smoothing factor from 0 and 1.

\section{MAPE AND MASE}

MAPE is the average of absolute error sum between the predicted and actual data divided by the actual data, and can be formulated as [18]

$$
M A P E=\left(\frac{1}{n} \sum_{t=1}^{n}\left|\frac{A_{t}-F_{t}}{A_{t}}\right|\right) \cdot 100 \%
$$


where $n$ refers to the total number of data, $A_{t}$ is the actual data, and $F_{t}$ is the forecasted data. In MAPE, the accuracy is expressed in percentage.

MASE is another unit-free forecast error method that was first introduced by Hyndman and Koehler [19]. It scales error based on the in-sample Mean Absolute Error (MAE) from naïve forecasting method that can be expressed as [20]

$$
M A S E=\operatorname{mean}\left(\left|\frac{A_{t}-F_{t}}{Q}\right|\right)
$$

where $A_{t}$ is the actual data, $F_{t}$ is the forecasted data, and $Q$ is a stable measure of the scale of the time series calculated on the training dataset, which can be found using [21]

$$
Q=\frac{1}{n-1} \sum_{i=2}^{n}\left|A_{i}-A_{i-1}\right|
$$

for non-seasonal time series data, and

$$
Q=\frac{1}{n-m} \sum_{i=\mathrm{m}+1}^{n}\left|A_{i}-A_{i-\mathrm{m}}\right|
$$

for seasonal time series data. Symbol $\boldsymbol{m}$ denotes the season length.

\section{INDONESIA'S EXPORT-IMPORT DATA}

To predict Indonesia's export and import performance, we take its export and import data from Badan Pusat Statistik (BPS) Indonesia [22]. BPS gives data in two different scales, i.e. the value in US $\$$ and the weight in $\mathrm{kg}$. Table 1 shows Indonesia's export-import data recorded from January 2015 to March 2018. These data will be used to predict future export-import value and

\begin{tabular}{|c|c|c|c|c|}
\hline \multirow{2}{*}{ Month } & \multicolumn{2}{|l|}{ Export } & \multicolumn{2}{|l|}{ Import } \\
\hline & Value (US \$) & Weight (KG) & Value (US \$) & Weight (KG) \\
\hline January 2015 & $13.244 .876 .797,53$ & $43.443 .195 .035,04$ & $12.612 .648 .838,00$ & $11.995 .411 .291,00$ \\
\hline February 2015 & $12.172 .802 .862,67$ & $39.768 .342 .676,62$ & $11.510 .111 .399,00$ & $12.134 .877 .571,00$ \\
\hline March 2015 & $13.634 .041 .965,14$ & $48.209 .231 .343,05$ & $12.608 .691 .718,00$ & $12.815 .242 .585,00$ \\
\hline April 2015 & $13.104 .596 .804,38$ & $44.113 .167 .148,17$ & $12.626 .278 .785,00$ & $13.205 .353 .501,00$ \\
\hline May 2015 & $12.754 .659 .043,69$ & $41.543 .644 .059,26$ & $11.613 .585 .485,00$ & $11.452 .923 .855,00$ \\
\hline June 2015 & $13.514 .101 .879,06$ & $40.886 .554 .950,92$ & $12.978 .091 .752,00$ & $12.789 .548 .820,00$ \\
\hline July 2015 & $11.465 .779 .764,41$ & $40.908 .711 .754,63$ & $10.081 .863 .504,00$ & $9.777 .959 .395,00$ \\
\hline August 2015 & $12.726 .037 .506,73$ & $41.703 .962 .147,89$ & $12.399 .248 .090,00$ & $12.392 .071 .524,00$ \\
\hline September 2015 & $12.588 .359 .370,70$ & $41.130 .727 .933,85$ & $11.558 .601 .330,00$ & $12.517 .106 .390,00$ \\
\hline October 2015 & $12.121 .740 .572,30$ & $43.492 .324 .675,64$ & $11.108 .916 .259,00$ & $11.725 .231 .343,00$ \\
\hline November 2015 & $11.122 .182 .554,29$ & $41.572 .222 .679,35$ & $11.519 .468 .515,00$ & $12.396 .999 .154,00$ \\
\hline December 2015 & $11.917 .112 .381,67$ & $42.889 .680 .221,37$ & $12.077 .298 .548,00$ & $13.890 .623 .811,00$ \\
\hline January 2016 & $10.581 .883 .837,98$ & $39.593 .480 .160,23$ & $10.466 .995 .371,00$ & $11.170 .356 .250,00$ \\
\hline February 2016 & $11.316 .734 .188,51$ & $38.699 .176 .125,86$ & $10.175 .631 .438,00$ & $12.777 .162 .927,00$ \\
\hline March 2016 & $11.812 .127 .477,93$ & $43.029 .049 .633,14$ & $11.301 .709 .941,00$ & $14.280 .888 .506,00$ \\
\hline April 2016 & $11.689 .745 .851,03$ & $39.558 .381 .868,75$ & $10.813 .624 .836,00$ & $12.028 .222 .569,00$ \\
\hline May 2016 & $11.517 .409 .125,88$ & $40.622 .406 .240,97$ & $11.140 .679 .613,00$ & $13.132 .879 .687,00$ \\
\hline June 2016 & $13.206 .122 .765,22$ & $44.766 .894 .584,67$ & $12.095 .220 .496,00$ & $13.501 .715 .838,00$ \\
\hline July 2016 & $9.649 .503 .975,97$ & $39.032 .046 .988,71$ & $9.017 .159 .102,00$ & $10.138 .881 .648,00$ \\
\hline August 2016 & $12.753 .921 .321,13$ & $45.800 .576 .791,74$ & $12.385 .153 .588,00$ & $14.001 .735 .399,00$ \\
\hline September 2016 & $12.579 .750 .249,95$ & $44.146 .271 .670,66$ & $11.297 .511 .237,00$ & $12.809 .168 .012,00$ \\
\hline October 2016 & $12.743 .736 .883,72$ & $47.378 .384 .671,57$ & $11.507 .180 .543,00$ & $12.391 .159 .183,00$ \\
\hline November 2016 & $13.502 .920 .382,69$ & $46.606 .206 .087,96$ & $12.669 .434 .720,00$ & $12.804 .703 .935,00$ \\
\hline December 2016 & $13.832 .355 .186,41$ & $45.551 .700 .747,95$ & $12.782 .515 .616,00$ & $12.988 .497 .126,00$ \\
\hline January 2017 & $13.397 .676 .587,81$ & $43.565 .989 .974,33$ & $11.973 .765 .825,00$ & $11.677 .887 .405,00$ \\
\hline February 2017 & $12.615 .825 .080,54$ & $37.467 .776 .841,18$ & $11.359 .410 .570,00$ & $12.640 .301 .805,00$ \\
\hline March 2017 & $14.718 .477 .686,89$ & $47.776 .913 .741,86$ & $13.283 .186 .576,00$ & $13.474 .016 .869,00$ \\
\hline April 2017 & $13.269 .689 .617,58$ & $44.248 .565 .280,56$ & $11.950 .612 .898,00$ & $12.432 .054 .822,00$ \\
\hline May 2017 & $14.333 .859 .523,55$ & $44.049 .700 .226,86$ & $13.772 .553 .263,00$ & $14.996 .662 .995,00$ \\
\hline June 2017 & $11.661 .376 .380,86$ & $39.899 .123 .547,30$ & $9.991 .567 .566,00$ & $11.067 .266 .662,00$ \\
\hline July 2017 & $13.611 .062 .499,27$ & $45.104 .086 .462,25$ & $13.889 .809 .439,00$ & $13.474 .009 .387,00$ \\
\hline August 2017 & $15.187 .990 .996,89$ & $47.603 .859 .326,86$ & $13.509 .196 .595,00$ & $14.290 .326 .822,00$ \\
\hline September 2017 & $14.580 .216 .111,80$ & $48.289 .451 .395,64$ & $12.788 .291 .967,00$ & $13.017 .265 .351,00$ \\
\hline October 2017 & $15.252 .563 .526,06$ & $50.820 .828 .191,65$ & $14.249 .179 .382,00$ & $14.703 .970 .178,00$ \\
\hline November 2017 & $15.334 .735 .600,61$ & $47.905 .955 .325,27$ & $15.113 .523 .078,00$ & $14.557 .794 .980,00$ \\
\hline December 2017 & $14.864 .547 .089,61$ & $49.114 .346 .862,32$ & $15.104 .466 .563,00$ & $14.417 .729 .365,00$ \\
\hline January 2018 & $14.553 .404 .792,01$ & $48.201 .600 .004,83$ & $15.309 .429 .258,00$ & $13.227 .092 .240,00$ \\
\hline February 2018 & $14.132 .633 .647,88$ & $46.062 .236 .353,82$ & $14.185 .493 .772,00$ & $13.779 .364 .997,00$ \\
\hline March 2018 & $15.586 .866 .516,52$ & $52.335 .443 .378,38$ & $14.463 .601 .047,00$ & $12.979 .524 .178,00$ \\
\hline
\end{tabular}
weight using hybrid moving average approach.

TABLE I. INDONESIA'S EXPORT-IMPORT DATA GROUPED BY MONTH 


\section{RESULTS AND DISCUSSION}

In this study, we tried to predict Indonesia's export and import performance by using historical data as shown in Table 1 . To predict the future values, we used WEMA method as a hybrid moving average approach in time series forecasting. Different parameter values, especially for the span number, will be taken into consideration. Two forecast error measurement tools being used are MAPE and MASE criteria.

Moreover, in the earlier study [23], we have developed a web-based forecasting tool known as Phatsa. It stands for PHP Application for Time Series Analysis, and can be accessed freely on http://phatsa.com. Phatsa has accommodated three different conventional moving average techniques, i.e. Simple Moving Average (SMA), Weighted Moving Average (WMA), and
Exponential Moving Average (EMA). During this study, we also implemented and integrated Weighted Exponential Moving Average (WEMA) as a hybrid moving average method in Phatsa. Then, it will be used as a forecasting tool in predicting Indonesia's exportimport data.

The prediction results of Indonesia's export-import data will be divided into several parts as can be seen in following figures. Figure 2 depicts the forecasting results of Indonesia's export value in US \$, while Figure 3 shows the forecasting results of Indonesia's export in weight unit. Figure 4 shows the forecasting results of Indonesia's import value in US \$, and Figure 5 depicts the forecasting results of Indonesia's import in weight unit. All the results shown here are the scenario results for parameters where span number is 3 , start index is 3 , and prediction period is 1 .

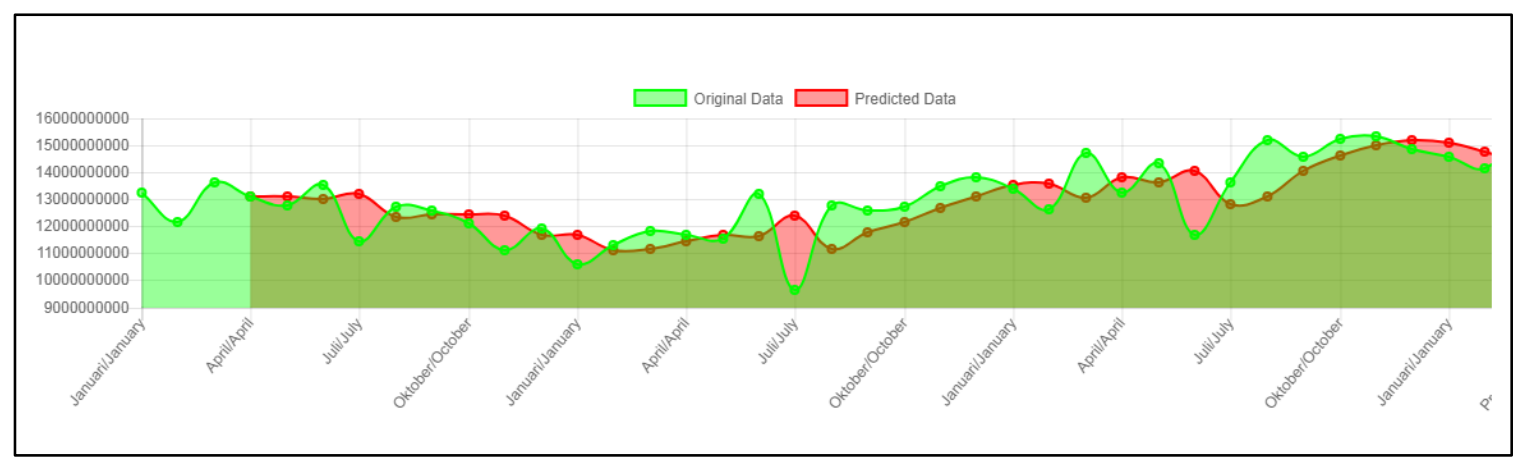

Fig 2 Indonesia's export in US \$

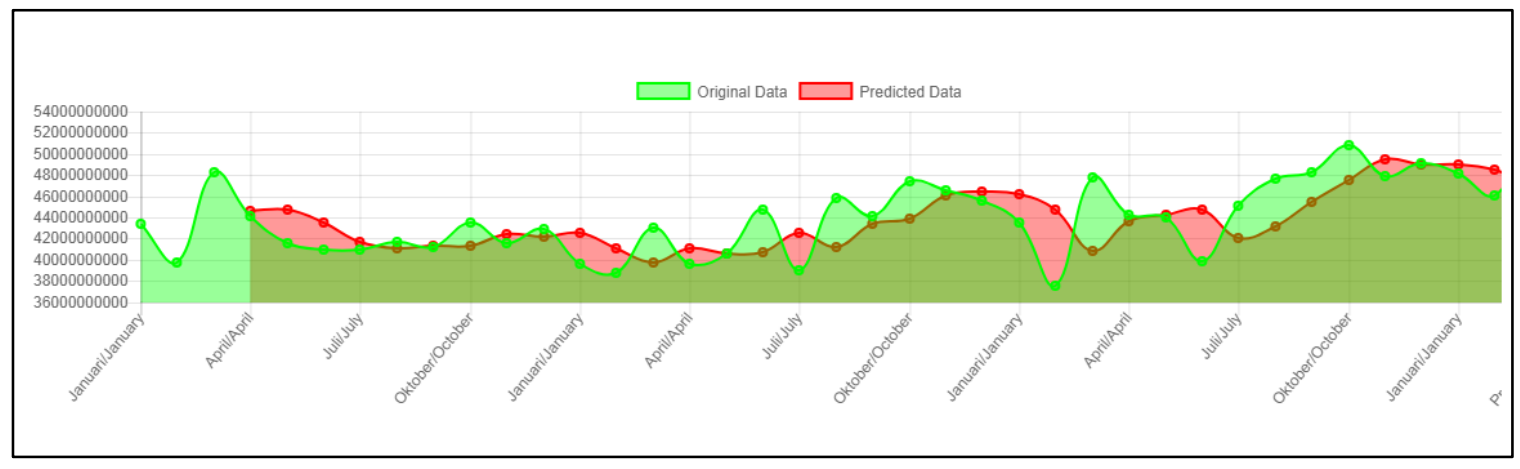

Fig 3 Indonesia's export in weight unit 


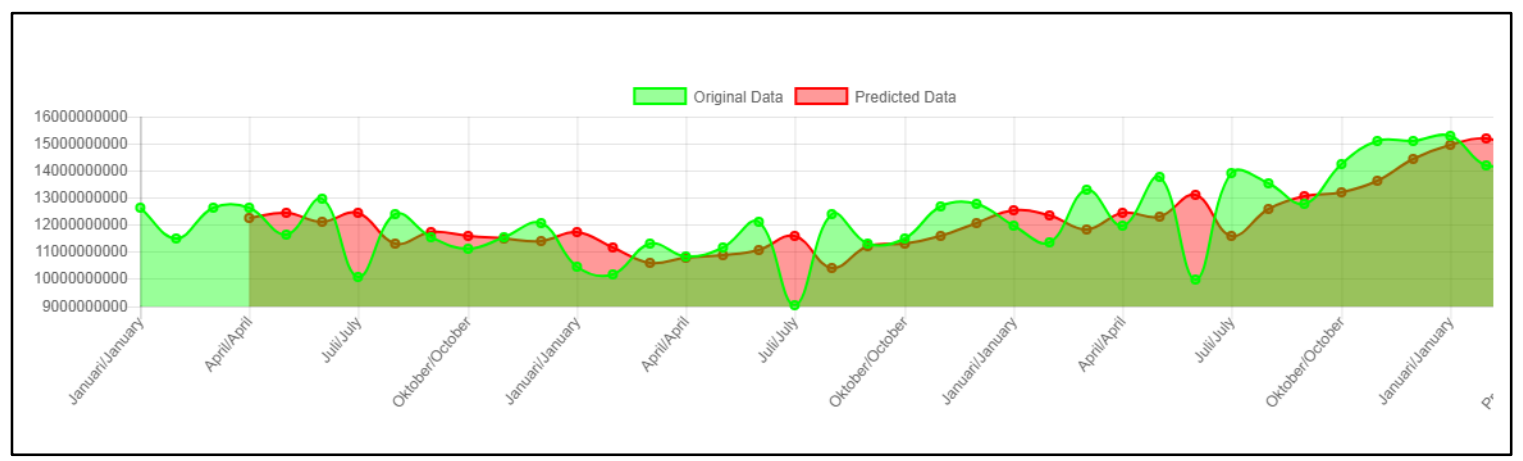

Fig 4 Indonesia's import in US \$

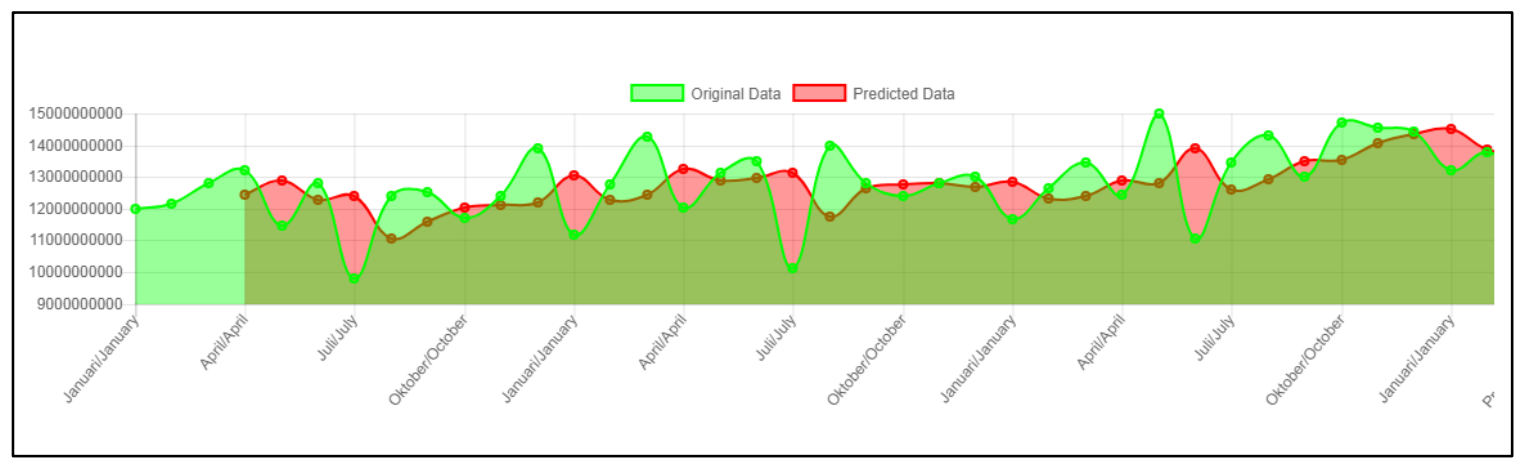

Fig 5 Indonesia's import in weight unit

The graphs have depicted the prediction results for Indonesia's export and import values in US \$ and weight units, and give us an initial understanding of the prediction performance. Furthermore, we used MAPE and MASE criteria to get the forecast error measurement for all the scenarios taken. We used different values for forecasting parameters, i.e. the span number and the start index, started from 2 to 12 . The prediction period will be set to 1 , which means that we will just forecast one step ahead.

Table 2 shows the MAPE and MASE values for Indonesia's export data prediction using WEMA approach, while the prediction error values for Indonesia's import data is shown in Table 3.

TABLE II. INDONESIA'S EXPORT ERROR RESULTS

\begin{tabular}{|l|r|r|r|r|}
\hline \multirow{2}{*}{ WEMA parameters } & \multicolumn{2}{|l|}{ Export Value (US \$) } & \multicolumn{2}{l|}{ Export Weight (kg) } \\
\cline { 2 - 5 } & \multicolumn{1}{|l|}{ MAPE } & \multicolumn{1}{l|}{ MASE } & \multicolumn{1}{l|}{ MAPE } & \multicolumn{1}{l|}{ MASE } \\
\hline span=2, start=2 & 6.86461 & 0.806631 & 5.819393 & 0.699131 \\
\hline span=3, start=3 & $\mathbf{6 . 5 0 7 9 6 3}$ & $\mathbf{0 . 6 4 7 0 5}$ & 5.444389 & $\mathbf{0 . 3 9 3 7 5}$ \\
\hline span=4, start=4 & 6.520325 & 0.807983 & 5.551444 & 0.450357 \\
\hline span=5, start=5 & 6.628838 & 0.985657 & 5.405014 & 0.505355 \\
\hline span=6, start=6 & 6.773995 & 1.028225 & $\mathbf{5 . 4 0 1 0 1 5}$ & 0.611888 \\
\hline span=7, start=7 & 6.54835 & 0.80517 & 5.497724 & 0.748341 \\
\hline span=8, start=8 & 6.746013 & 0.802394 & 5.719806 & 0.873319 \\
\hline span=9, start=9 & 6.959836 & 0.928563 & 5.885778 & 0.999385 \\
\hline span=10, start=10 & 7.09549 & 1.004462 & 5.982194 & 1.027208 \\
\hline span=11, start=11 & 6.987512 & 0.984608 & 6.117694 & 1.079457 \\
\hline span=12, start=12 & 7.245884 & 1.032555 & 6.25473 & 1.154421 \\
\hline Average & 6.807165 & 0.893936 & $\mathbf{5 . 7 3 4 4 7 1}$ & $\mathbf{0 . 7 7 6 6 0 1}$ \\
\hline
\end{tabular}

TABLE III. INDONESIA’S IMPORT ERROR RESULTS

\begin{tabular}{|l|l|l|l|l|}
\hline \multirow{2}{*}{ WEMA parameters } & \multicolumn{2}{|l|}{ Import Value (US \$) } & \multicolumn{2}{l|}{ Import Weight (kg) } \\
\cline { 2 - 5 } & MAPE & MASE & \multicolumn{1}{l|}{ MAPE } & \multicolumn{1}{l|}{ MASE } \\
\hline span=2, start=2 & 8.610572 & 0.920877 & 9.534107 & 8.456282 \\
\hline span=3, start=3 & 8.065388 & 0.865397 & 8.286319 & 2.493844 \\
\hline span=4, start=4 & 8.102861 & 1.299089 & 8.177443 & 2.502791 \\
\hline
\end{tabular}


Hansun, Kristanda, \& Winarno / Journal of Engineering and Science Research, 2(6) 2018, Pages: 37-43

\begin{tabular}{|l|r|r|r|r|}
\hline span=5, start=5 & 8.055452 & 1.188011 & 7.962693 & 1.334172 \\
\hline span=6, start=6 & 8.018358 & 1.040657 & 7.841472 & 1.134464 \\
\hline span=7, start=7 & $\mathbf{7 . 5 4 0 7 8 5}$ & 0.73304 & 7.14548 & 0.749398 \\
\hline span=8, start=8 & 7.713197 & $\mathbf{0 . 6 6 6 7 0 5}$ & 7.161624 & $\mathbf{0 . 6 4 7 0 7 6}$ \\
\hline span=9, start=9 & 7.883142 & 0.717899 & 7.120864 & 0.727803 \\
\hline span=10, start=10 & 8.011406 & 0.790728 & 7.258064 & 0.775697 \\
\hline span=11, start=11 & 8.320209 & 0.882032 & 7.359684 & 0.824803 \\
\hline span=12, start=12 & 8.547888 & 0.952831 & $\mathbf{7 . 0 9 6 7 5 7}$ & 0.771792 \\
\hline Average & 8.079023 & 0.914297 & 7.722228 & 1.856193 \\
\hline
\end{tabular}

From Table 2, we could infer that the best scenario to predict Indonesia's export future values is by using span number and start index equals to 3 since it gave the smallest MAPE and MASE forecast error values among other scenarios. However, for Indonesia's import values, it seems that there is no preference scenario since the smallest MAPE and MASE values are scattered in different parameter values.

Among all the dataset studied in this research, i.e. the export value in US \$, export weight in $\mathrm{kg}$, import value in US \$, and import weight in $\mathrm{kg}$, it's found that WEMA approach could best predict the export weight in $\mathrm{kg}$, since it gave the smallest MAPE average value at $5.734471 \%$ and smallest MASE average value at 0.776601 .

\section{CONCLUSION}

The main focus of this study is to predict Indonesia's export-import data using hybrid moving average approach, in this case, the WEMA method. As has been shown, we have successfully predicted the export and import data using WEMA method which was integrated into Phatsa framework. Using different WEMA parameter values, it has been shown that WEMA could give forecasting results with different forecasting error values. Based on the MAPE and MASE criteria, prediction on Indonesia's export weight in $\mathrm{kg}$ unit using WEMA approach gives the best result. Moreover, the preference parameters for export data prediction are known to be 3 for the span number and start index, while for import data prediction there is no preference at all. In the future study, other variants of WEMA method, such as B-WEMA (Brown's Weighted Exponential Moving Average) and H-WEMA (Holt's Weighted Exponential Moving Average) could be integrated into Phatsa framework and be used to forecast Indonesia's export-import data as a comparison with this study. Another study to combine different zero-lag moving average approach (for example Hull Moving Average) can also be taken to develop a new hybrid variant of moving average methods.

\section{ACKNOWLEDGMENTS}

This research is supported and sponsored by the Ministry of Research, Technology and Higher Education of the Republic of Indonesia (Kemenristekdikti) under the 'Penelitian Strategis Nasional - Institusi' grant no. 604/LPPM$\mathrm{UMN} / \mathrm{II} / 2018$.

\section{REFERENCES}

[1] A. Keck, A. Raubold, A. Truppia. Forecasting International Trade: A Time Series Approach. [Online] Available: https://www.econjobs.com/research/36056-Forecastinginternational-trade-A-time-series-approach.pdf

[2] Ministry of Trade of Republic of Indonesia. [Online] Available: http://www.kemendag.go.id/id/economicprofile/10-main-and-potential-commodities/10main-commodities

[3] Badan Pusat Statistik. Buletin Statistik Perdagangan Luar Negeri: Ekspor, Menurut Kelompok Komoditi dan Negara Oktober 2017. Jakarta: Badan Pusat Statistik, 2017.

[4] M. Sultan and K. Munir. Export, Import and Total Trade Potential of Pakistan: A Gravity Model Approach. MPRA Paper No. 66621. [Online] Available: https://mpra.ub.unimuenchen.de/66621/1/MPRA_paper_66621.pdf

[5] Darman. Perdagangan Luar Negeri IndonesiaAmerika Serikat. Binus Business Review, vol.4, no.2, pp.742-755, 2013.

[6] F. Ustriaji. Analisis Daya Saing Komoditi Ekspor Unggulan Indonesia di Pasar Internasional. Jurnal Ekonomi Pembangunan, vol.14, no.2, pp.149-159, 2016.

[7] H. Cetintas and S. Barisik. Export, Import and Economic Growth: The Case of Transition Economies. Transition Studies Review, vol.15, no.4, pp.636-649, 2009.

[8] N. Dasgupta. Examining the Long Run Effects of Export, Import and FDI Inflows on the FDI Outflows from India: A Causality Analysis. Journal of International Business and Economy, vol.10, no.1, pp.65-88, 2009. 
[9] T. Velnampy and S. Achchuthan. Export, Import and Economic Growth: Evidence from Sri Lanka. Journal of Economics and Sustainable Development, vol.4, no.9, pp.147-155, 2013.

[10] M. Chen, T. Jiang, W. Zou. Differential Physical Layer Secret Key Generation Based on Weighted Exponential Moving Average. Proceedings of 9th International Conference on Signal Processing and Communication Systems (ICSPCS). Australia. 2015.

[11] S. Hansun. Penerapan WEMA dalam Peramalan Data IHSG. ULTIMATICS, vol.5, no.2, pp.63-66, 2013.

[12] S. Hansun, M. B. Kristanda, V. Charles. WEMA Implementation in FX Forecasting. Unpublished.

[13] S. Hansun, M. B. Kristanda, P. M. Winarno. Big 5 ASEAN Capital Markets Forecasting using Hybrid WEMA Method. Unpublished.

[14] S. Hansun. A New Approach of Moving Average Method in Time Series Analysis. Proceedings of the 2013 IEEE International Conference on New Media (CoNMedia). Tangerang, Indonesia. 2013, pp.1-4.

[15] V. Zakamulin. Market Timing with Moving Averages: Anatomy and Performance of Trading Rules. May 2016. [Online] Available: https://ssrn.com/abstract=2585056

[16] E. S. Gardner. Exponential Smoothing: The State of the Art - Part II. International Journal of Forecasting, vol. 22, no. 4, pp. 637-666, 2006.

[17] S. Hansun and M. B. Kristanda. Performance Analysis of Conventional Moving Average Methods in Forex Forecasting. Proceedings of 2017 International Conference on Smart Cities, Automation \& Intelligent Computing Systems. Yogyakarta, Indonesia. 2017.

[18] Y. Asultanny. Successful Forecasting for Knowledge Discovery by Statistical Methods. Proceedings of 9th International Conference on Information Technology: New Generations, Las Vegas, USA, 2012, pp. 584-588.

[19] R. J. Hyndman and A. B. Koehler. Another Look at Measures of Forecast Accuracy. International Journal of Forecasting, vol.22, no.4, pp.679-688, 2006.

[20] R. J. Hyndman. Another Look at ForecastAccuracy Metrics for Intermittent Demand. Foresight, vol.4, pp.43-46, 2006.

[21] R. J. Hyndman and G. Athanasopoulos. Forecasting: Principles and Practice. Melbourne, Australia: OTexts, 2013.

[22] Badan Pusat Statistik. Ekspor dan Impor. [Online] Available:

https://www.bps.go.id/all_newtemplate.php

[23] M. B. Kristanda and S. Hansun. Phatsa: A WebBased Application for Forecasting using Conventional Moving Average Methods.
Proceedings of 4th International Conference on New Media. Yogyakarta, Indonesia. 2017. 